\title{
Variaciones termodinámicas de la descarbonatación de un crudo conteniendo cenizas volantes bajas en cal
}

\section{Thermodynamic variations in the decarbonation of low calcium fly ash-cement raw mix}

\author{
I. ELKHADIRI $^{(*)}, \underline{A}$. DIOURI $^{(* *)}$, A. BOUKHARI ${ }^{(* *)}$, J. ROGEZ ${ }^{(* *)}$ \\ ${ }^{(*)}$ Instituto de Ciencias de la Construcción «Eduardo Torroja». CSIC. Madrid, \\ ${ }^{(* *)}$ Laboratoire de Chimie du Solide Appliquée, Laboratoire Associé Francophone 501, \\ Faculté des Sciences Université Mohammed V-Agdal, Rabat, \\ ${ }^{(*+\star)}$ Laboratoire TECSEN, Faculté des Sciences et Techniques de St Jérôme Aix-Marsella, \\ Persona de contacto/Corresponding author: diouri(a,fsr.ac.ma
}

Fecha de recepción: $16-\mathrm{XII}-03$

Fecha de aceptación: 4-IV-04

ESPAÑA, MARRUECOS, FRANCIA

\section{RESUMEN}

El objetivo del presente trabajo es estudiar durante su tratamiento térmico, alrededor de $1.000{ }^{\circ} \mathrm{C}$, la evolución de la descomposición de un crudo que posee un factor de saturación de cal (LSF) bajo. Este crudo se ha elaborado adicionando cenizas volantes bajas en calcio a un crudo de cemento portland ordinario.

La temperatura de descarbonatación y la variación de la cntalpia durante la descomposición de la calcita se determinan por ATD y calorimetria isotérmica. Los resultados muestran la formación de un clinker belitico con un LSF entre $85 y$ 75\%. Asimismo, se demuestra que la presencia de cenizas volantes retarda el comienzo de la descarbonatación y disminuye la temperatura máxima y final del proceso de descarbonatacion. El lalor de la entalpia de la descarbonatación disminuye con la presencia de cenizas volantes.

\section{SUMMARY}

In this paper; the authors analyse the decomposition of a low lime saturation factor (LSF) raw mix -obtained by adding low: calcium fly ash to standard portland cement- when heated to around $1000^{\circ} \mathrm{C}$.

The decarbonation temperatures and variation in enthalpy taking place during calcite decomposition were determined by DTA and isothermal calorimetric measurement. The resulting belitic clinker had a LSF factor ranging from 75 to $85 \%$. The presence of fly ash was observed to retard the onset of decarbonation and lower the peak and final decarbonation temperatures. Decarbonation enthalpy was also found to decrease with fly ash content.
PALABRAS CLAVE: cenizas volantes, descarbonatación, análisis térmico, calorimetría isotérmica.

\section{INTRODUCCIÓN}

El crudo de cemento portland se obtiene generalmente a partir de la mezcla de un material calcáreo, normalmente la caliza, con una proporción menor de un material arcilloso. Esas materias primas se mezclan íntimamente y se calientan hasta $1.450^{\circ} \mathrm{C}$.
KEYWORDS: fly ash, decarbonation, thermal analysis, isothermal calorimetry.

\section{INTRODUCTION}

Raw portland cement mixes are generally obtained by blending a calcareous material, typically limestone, with a smaller amount of clay or shale, and then heating the raw materials at temperatures of up to $1450{ }^{\circ} \mathrm{C}$. 
La "aptitud a la cocción" de un crudo de cemento ha sido definida por la cantidad de cal libre que permanece en el producto después de un determinado tratamiento térmico o por el tiempo que es necesario emplear en dicho tratamiento para que el contenido de cal libre se reduzca hasta un valor determinado (1). Las características químicas y físicas del crudo influyen en la aptitud a la cocción y en la calidad del clínker. Numerosos estudios han demostrado que la facilidad de clinkerización de un crudo aumenta con la disminución de su "factor de saturación de cal" (LSF):
The burnability of a raw mix is ordinarily defined in terms of the quantity of free lime present after a specific heat treatment, or by the time the mix must be heated to reduce the free lime content to some predetermined value (1). The burnability and quality of the clinker are affected by the chemical and physical properties of the raw mix. Many studies have shown that the burnability of the raw materials used to produce Portland clinker rises as the lime saturation factor (LSF) declines:

$$
\text { LSF }=\frac{\mathrm{CaO}}{2,8 \mathrm{SiO}_{2}+1,2 \mathrm{Al}_{2} \mathrm{O}_{3}+0,65 \mathrm{Fe}_{2} \mathrm{O}_{3}}
$$

Cementos fabricados a partir de crudos con bajo LSF tienen ventajas medioambientales. La modificación del LSF induce, asimismo, modificaciones de los otros dos módulos, de sílice (SR) y de aluminatos (AR). La modificación de esos factores actúa directamente en el proceso de descarbonatación. Algunos autores $(2,3)$ han señalado que la velocidad a la que reacciona la cal libre depende no solamente de las características del crudo y de la atmósfera del horno, sino también del tratamiento térmico recibido antes de penetrar en la zona de clinkerización. La cinética de descarbonatación ha sido estudiada por numerosos científicos de todo el mundo, ya que la modificación de la entalpía total durante la formación del clínker se rige por la descarbonatación endotérmica de la calcita, lo que requiere un alto consumo de energía, entre 1.776 y $1.785 \mathrm{~J} / \mathrm{g}(4-6)$.

En el presente trabajo se discute el efecto de la reducción del módulo de saturación de cal (LSF) en la cinética de la descarbonatación de la calcita en un crudo de cemento portland que contiene cenizas volantes bajas en cal (CV) en su composición. Las temperaturas de descarbonatación se determinan con Análisis Térmico Diferencial (ATD). Se utiliza un Calorímetro Isotérmico para estudiar los cambios de entalpía durante la descarbonatación.

\section{EXPERIMENTAL}

La composición química de las materias primas (CV bajas en cal y crudo portland) se da en la Tabla 1. Las muestras se prepararonn mezclando las $\mathrm{CV}$ con el crudo, en proporciones determinadas, en un mortero de ágata con etanol absoluto, durante treinta minutos. En las Tablas 2 y 3 se dan las proporciones de las muestras y las correspondientes composiciones químicas. La cantidad de cada una de las muestras se determina considerando que el LSF correspondiente ha de estar situado entre valores de $75 \mathrm{y}$ $85 \%$.
Cement with low LSF is advantageous from the standpoint of environmental conservation, but modification of this parameter entails changes in two other factors, namely the silica and the alumina ratios. Such changes have a direct impact on the decarbonation process. Some authors $(2,3)$ report that the rate at which free lime reacts depends not only on raw mix characteristics and kiln atmosphere, but also on the heat treatment received before entering the clinkering zone, when decarbonation takes place. Decarbonation kinetics have attracted a great deal of attention worldwide, because the primary process in the overall variation in enthalpy during clinker formation is the strongly endothermic decomposition of calcite, which consumes energy at a rate of from 1776 to $1785 \mathrm{~J} / \mathrm{g}(4-6)$.

This paper addresses the effect of reducing the lime saturation factor (LSF) on the kinetics of calcite decomposition in an ordinary Portland raw mix by adding low calcium fly ash. The decarbonation temperatures were determined with differential thermal analysis (DTA) and enthalpimetric techniques were used to monitor the changes in enthalpy.

\section{EXPERIMENTAL}

The chemical composition of the initial materials, (class F) low calcium fly ash and standard raw mix, is given in Table 1. The samples were prepared by blending the standard raw mix and low calcium fly ash in different proportions ( $x \%$ by weight) in agate mortar with absolute ethanol for about $30 \mathrm{~min}$. Tables 2 and 3 show the mix design and respective chemical compositions. The samples were proportioned to have a LSF factor of from 75 to $85 \%$. 
TABLA $1 /$ TABLE 1

Composición química de los materiales (\% en peso)

Chemical composition of the initial materials (wt.\%)

\begin{tabular}{|l|c|c|c|c|c|c|c|c|}
\hline & $\mathrm{SiO}_{2}$ & $\mathrm{Al}_{2} \mathrm{O}_{3}$ & $\mathrm{CaO}$ & $\mathrm{Fe}_{2} \mathrm{O}_{3}$ & $\mathrm{MnO}$ & $\mathrm{P}_{2} \mathrm{O}_{5}$ & $\mathrm{TiO}_{2}$ & LOI \\
\hline Crudo (Raw mix) & 14.00 & 3.03 & 42.85 & 2.94 & 0.08 & 0.36 & 0.49 & 34.91 \\
\hline Ceniza volante(Fly ash) & 48.33 & 30.62 & 7.00 & 5.10 & 0.14 & 0.93 & 1.45 & 4.78 \\
\hline
\end{tabular}

TABLA 2/TABLE 2

Muestras proporcionadas (\% en peso)

Sample proportioning (wt.\%)

\begin{tabular}{|c|c|c|c|c|c|c|}
\hline & $\mathrm{RF}_{0}$ & $\mathrm{RF}_{3.42}$ & $\mathrm{RF}_{4.50}$ & $\mathrm{RF}_{5.50}$ & $\mathrm{RF}_{5.70}$ & $\mathrm{RF}_{6}$ \\
\hline Crudo (Raw mix) & 100 & 96.58 & 95.50 & 94.50 & 94.30 & 94.00 \\
\hline Ceniza volante (Fly ash) & 0 & 3.42 & 4.50 & 5.50 & 5.70 & 6.00 \\
\hline
\end{tabular}

TABLA 3/TABLE 3

Composición química de las muestras (\% en peso) y valor del módulo Chemical composition of samples (wt.\%) and modulus values

\begin{tabular}{|c|c|c|c|c|c|c|c|}
\hline & $\mathrm{SiO}_{2}$ & $\mathrm{Al}_{2} \mathrm{O}_{3}$ & $\mathrm{CaO}$ & $\mathrm{Fe}_{2} \mathrm{O}_{3}$ & LSF & SR & AR \\
\hline $\mathrm{RF}_{0}$ & 14.00 & 3.03 & 42.85 & 2.94 & 95.89 & 2.34 & 1.03 \\
\hline $\mathrm{RF}_{3.42}$ & 15.17 & 3.97 & 41.62 & 3.01 & 84.74 & 2.17 & 1.32 \\
\hline $\mathrm{RF}_{4.50}$ & 15.54 & 4.27 & 41.24 & 3.04 & 81.62 & 2.13 & 1.40 \\
\hline $\mathrm{RF}_{5.50}$ & 15.89 & 4.55 & 40.88 & 3.06 & 78.84 & 2.09 & 1.49 \\
\hline $\mathrm{RF}_{5.70}$ & 15.96 & 4.60 & 40.81 & 3.06 & 78.65 & 2.08 & 1.50 \\
\hline $\mathrm{RF}_{6}$ & 16.06 & 4.69 & 40.70 & 3.07 & 77.53 & 2.07 & 1.53 \\
\hline
\end{tabular}

Las temperaturas de descarbonatación se determinaron por ATD con una velocidad de calentamiento de $10{ }^{\circ} \mathrm{C} /$ minuto, en muestras de $300-400 \mathrm{mg}$. El termopar utilizado fue de $\mathrm{Pt} / \mathrm{Pt}-\mathrm{Rh}$, al $10 \%$ en peso. Las variaciones de entalpía se determinaron a través de las medidas de un Calorímetro Isotérmico Tian Calvet $\left(\mathrm{T}=1.100^{\circ} \mathrm{C}\right)$, con termopar Pt/Pt-Rh (13\% en peso) (7). La calibración del calorímetro se realizó con muestras certificadas NBS de alúmina de masa determinada en las mismas condicio-
The decarbonation temperatures were measured by DTA at a heating rate of approximately $10^{\circ} \mathrm{C} / \mathrm{min}$ on samples weighing 300-400 $\mathrm{mg}$, with a Pt/Pt (10\%wt Rh) thermocouple. Variations in enthalpy were measured with a Tian Calvet isothermal calorimeter $\left(T \sim 1100^{\circ} \mathrm{C}\right)$, using a Pt/Pt (13\% wt Rh) thermocouple (7). The calorimeter was calibrated with NBS-certified alumina samples of a 
nes que las muestras en estudio (8). Durante los ensayos, se fijó una temperatura determinada en el calorímetro, la muestra (alrededor de unos $50 \mathrm{mg}$ ) se introduce en el calorímetro a la temperatura predeterminada, 1.020, 1.126 y $1.237 \mathrm{~K}$. La integración del termograma es proporcional a la suma del contenido calorífico de los materiales que están reaccionando y de las entalpías de las reacciones que transcurren mientras se realiza el proceso de medidas.

\section{RESULTADOS}

\subsection{Análisis Térmico Diferencial}

Los termogramas de las muestras se dan en la Figura 1. Todos ellos presentan un pico que es característico de descarbonatación, como se puede comprobar en la Figura 2. $T_{h}$ indica la temperatura al comienzo de la descarbonatación; $T_{n}$, la temperatura correspondiente a la máxima velocidad de reacción, en el tiempo $t_{m}$ (el máximo del pico de ATD) y $T_{c}$ la temperatura en el final de la reacción. Se observa siempre entre los puntos $t_{1 n} y_{c}$ una variación brusca en el perfil del termograma lo que indica el fin de la descarbonatación.

La línea base antes y después del pico de descarbonatación es muy diferente a causa de la diferencia de las capacidades caloríficas de los componentes iniciales y de los que resultan al final de la reacción de descarbonatación. Por otra parte, la línea base del final se desplaza ligeramente hacia valores exotérmicos a causa del solapamiento de la descarbonatación, que es endotérmica, con la reacción exotérmica en su conjunto. Antes del valor $t_{\mathrm{e}}$ la influencia del efecto exotérmico sobre el endotérmico se considera prácticamente despreciable.

El área total de la superficie formada entre el pico y la línea base modificada se atribuye, en una primera aproximación, a la entalpia de la descarbonatación y se mide por la integración de dicha área (Figura 2). El desarrollo de la reacción puede observarse en la evolución de la curva y en particular en $t_{m}$.

Las temperaturas de descarbonatación se dan en la Tabla 4 , y su variación en función del tanto por ciento en peso de C.V. en las muestras se representa en la Figura 3. Se observa que el aumento en la proporción de C.V. conduce a un aumento de la temperatura del comienzo de la descarbonatación y a una disminución de la temperatura del final y de la máxima velocidad de descarbonatación.

La evolución de la reacción de descarbonatación en el tiempo $t_{\mathrm{m}}$ es prácticamente constante, con errores despreciables. Se ha calculado en torno al $62 \%$, pero es con seguridad más bajo debido a la pérdida de información en el final del termograma a causa del mencionado efecto exotérmico. known mass analysed under the same conditions as the samples (8). To run the experiments, the sample (about $50 \mathrm{mg}$ ) was placed in the calorimeter and heated from the laboratory to the pre-set temperature-1020,1126 or $1237 \mathrm{~K}$. The integration of the thermogram is proportional to the sum of the heat contents of the reagents and the enthalpies of the reactions occurring as the measurements were taken.

\section{RESULTS}

\subsection{Differential Thermal Analysis}

The thermograms of all the samples, shown in Figure 1, have typical decarbonation peaks such as the one shown in Figure 2. $T_{b}$ is the temperature at which decarbonation begins, $T_{m}$ the temperature at the maximum reaction rate, at time $t_{m}$ (the tip of the DTA peak), and $T_{e}$ the temperature at the end of the reaction. The steep decline in the slope between $t_{m}$ and $t_{e}$ in all the thermograms marks the end of decarbonation.

The baseline values before and after the peak differ substantially because of the different heat capacities of the initial components and the final decarbonation products. Moreover, the final baseline shifts slightly towards exothermic values as a result of the net effect of decarbonation, which is endothermic, and the exothermic balance of the reaction as a whole. Before $t_{e^{\prime}}$ the impact of the exothermic part of the reaction on the endothermocity of decarbonation is regarded to be negligible.

The total area between the peak and the modified base line is roughly attributed to decarbonation enthalpy and is measured (Figure 2) by partial integration. The curve, in particular at $t_{m}$, reflects reaction progress.

The decarbonation temperatures are listed in Table 4 and their variation with the percentage (by weight) of fly ash in the samples is plotted in Figure 3. Higher fly as content is observed to lead to a rise in the temperature at which decarbonation begins and a decline in the final and peak decarbonation temperatures.

The decarbonation reaction is practically constant at $t_{m}$, within an acceptable margin of error. The actual value is certain to be lower than the $62 \%$ measured, given the loss of information at the end of the thermogram as a result of the exothermic reaction. 


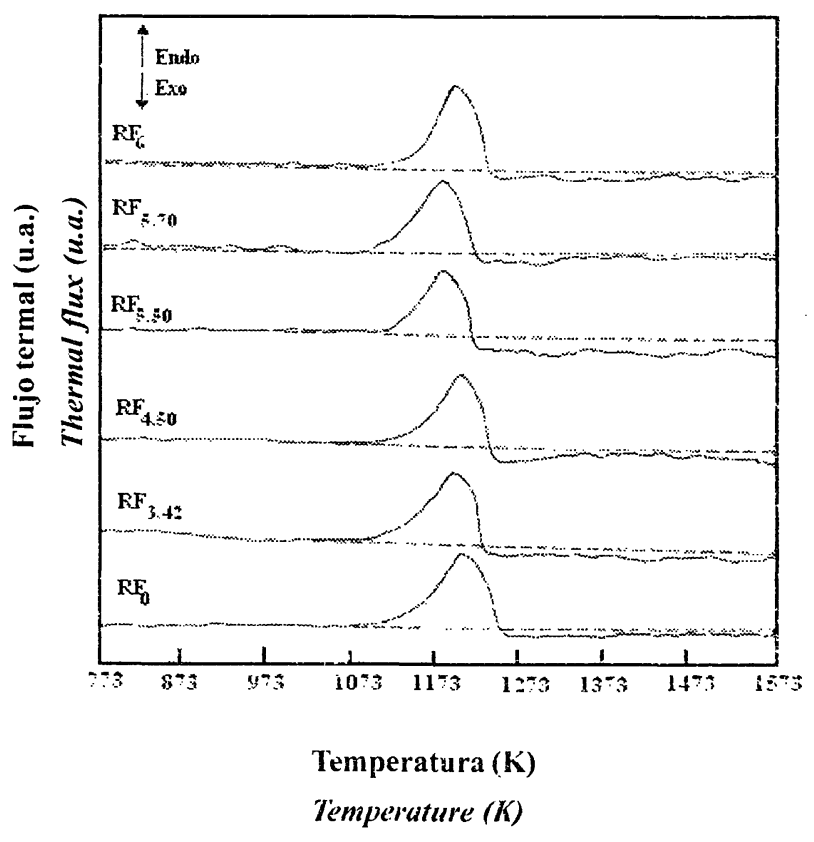

Figura 1.- Termograma de DTA.

Figure 1.- DTA thermograms.

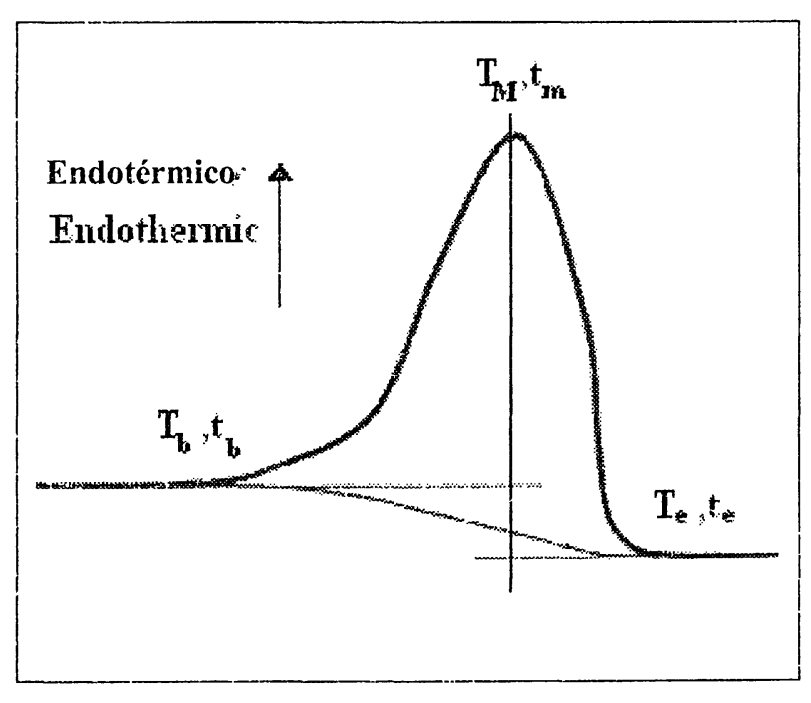

Figura 2.- Termograna tipico.

Figure 2.- Typical thermogranis.

TABLA 4/TABLE 4

Temperaturas de descarbonatación y fracción del área en el momento $\mathrm{t}_{\mathrm{m}}$ Decarbonation temperatures and fraction of area at $t_{n}$

\begin{tabular}{|c|c|c|c|c|c|}
\hline \multirow{2}{*}{$\begin{array}{l}\text { Muestra } \\
\text { Sample }\end{array}$} & \multicolumn{3}{|c|}{$\begin{array}{l}\text { Temperatura }(\mathrm{K}) \\
\text { Temperature }(K)\end{array}$} & \multirow[t]{2}{*}{$\mathrm{t}_{\mathrm{m}} / \mathrm{t}_{\mathrm{c}}$} & \multirow[t]{2}{*}{ Area $\%$ at $\mathrm{t}_{\mathrm{in}}$} \\
\hline & $T_{b}$ & $\Gamma_{\mathrm{m}}$ & $\Gamma_{0}$ & & \\
\hline $\mathrm{RF}_{0}$ & 1062 & 1215 & 1256 & 079 & 0.64 \\
\hline $\mathrm{RF}_{3.42}$ & 1070 & 1200 & 1240 & 0.78 & 0.61 \\
\hline $\mathrm{RF}_{4.50}$ & 1082 & 1205 & 1244 & 0.77 & 0.65 \\
\hline $\mathrm{RF}_{5.50}$ & 1097 & 1194 & 1235 & 0.68 & 0.61 \\
\hline $\mathrm{RF}_{5,70}$ & 1089 & 1191 & 1245 & 0.63 & 0.60 \\
\hline $\mathrm{RF}_{6}$ & 1091 & 1198 & 1244 & 0.669 & 0.63 \\
\hline
\end{tabular}

\subsection{Calorimetria isotérnica}

La dispersión de las medidas son: : $2,5 \%$ a $1.020 \mathrm{~K}$, algo mayor a $1.126 \mathrm{~K} \quad(-1 \%)$ y del $4 \%$ a $1.237 \mathrm{~K}$. Esas medidas se dan en la Tabla 5 y se representan en la Figura 4. A partir de esos resultados se observat que la entalpía global aumenta frente a la temperatura en ur: valor medio de $920 \mathrm{~J} / \mathrm{g}$ a $1.020 \mathrm{~K}$ y $3.040 \mathrm{~J} / \mathrm{g}$ a $1.237 \mathrm{~K}$.

\subsection{Measurenents by isothernal calorimetry}

The dispersion of the enthalpy values observed is as follow: $\pm 2.5 \%$ ' at $1020 \mathrm{~K}$, slightly higher (up to $\pm 8 \%$ at $1126 \mathrm{~K}$ and $1.4 \%$ at $1237 \mathrm{~K}$. These measurements are griven in Table 5 and plotied in Figure 4. The results show that global e:thalpy increased from an average value of 920 Jig at $1020 \mathrm{~K}$ to $3040 \mathrm{~J} / \mathrm{g}$ at $\mathrm{j} 237 \mathrm{~K}$. 


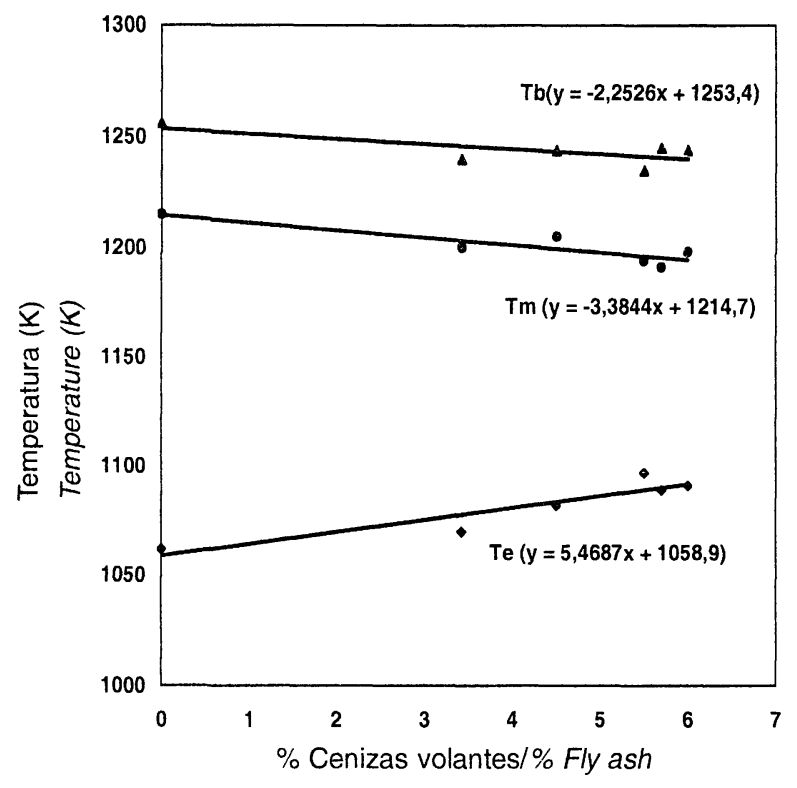

Figura 3.- La variación de las temperaturas de la descarburación en función de las cenizas volantes.

Figure 3.- Variation in descarbonation temperature as a function of fly ash content.

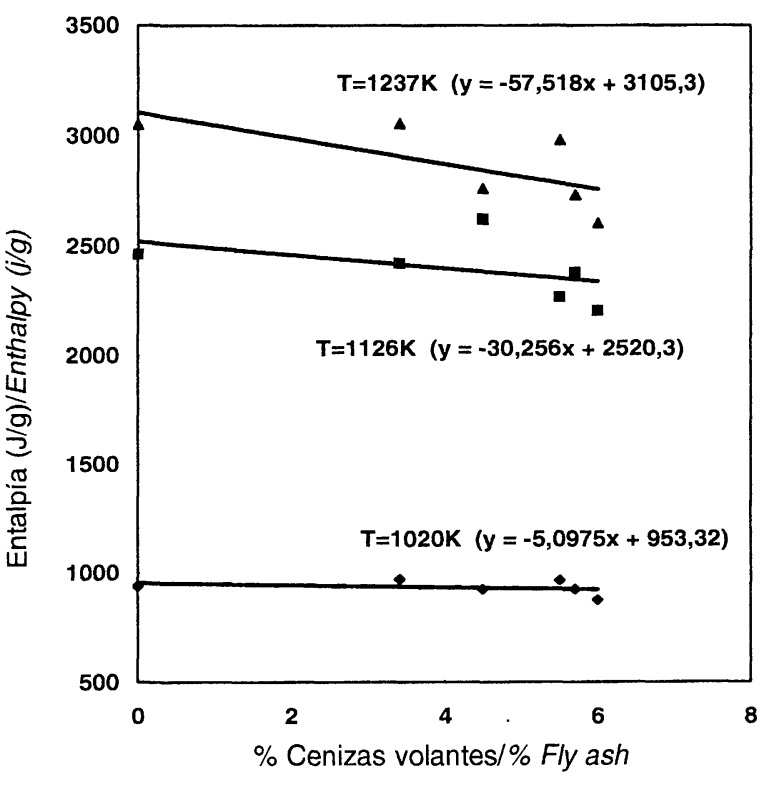

Figura 4.- Variación de la entalpia en función de la temperatura y de las cenizas volantes.

Figure 4.- Variation in enthalpy as a function of temperature and fly ash content.

TABLA 5/TABLE 5

Variación de la entalpía $(\mathrm{J} / \mathrm{g})$ en función de la temperatura

Enthalpy variation $(J / g)$ with temperature

\begin{tabular}{|c|c|c|c|}
\hline \multirow{2}{*}{$\begin{array}{c}\text { Muestra } \\
\text { Sample }\end{array}$} & \multicolumn{3}{|c|}{$\begin{array}{c}\text { Temperatura (K) } \\
\text { Temperature (K) }\end{array}$} \\
\cline { 2 - 4 } & 1020 & 1126 & 1237 \\
\hline $\mathrm{RF}_{0}$ & 937.72 & 2464.30 & 3049.91 \\
\hline $\mathrm{RF}_{3.42}$ & 969.00 & 2422.00 & 3054.06 \\
\hline $\mathrm{RF}_{4.50}$ & 923.00 & 2621.00 & 2762.31 \\
\hline $\mathrm{RF}_{5.50}$ & 965.00 & 2269.00 & 2982.00 \\
\hline $\mathrm{RF}_{5.70}$ & 922.14 & 2379.16 & 2733.74 \\
\hline $\mathrm{RF}_{0}$ & 875.00 & 2206.08 & 2605.01 \\
\hline
\end{tabular}

Respecto al contenido de cenizas volantes, las entalpías son constantes a $1.020 \mathrm{~K}$; a temperaturas de $1.126 \mathrm{~K}$ y $1.237 \mathrm{~K}$ son constantes para un contenido de cenizas volantes inferior al $4 \%$, pero para valores superiores al $4,5 \%$ se observa una disminución de la entalpía entre el 10 y el $15 \%$, aproximadamente.

\section{DISCUSIÓN}

La introducción de cenizas volantes bajas en cal en un crudo de cemento portland se manifiesta por una dismi-
Fly ash content has no effect on enthalpy at $1020 \mathrm{~K}$. At 1126 and $1237 \mathrm{~K}$, enthalpy is constant up to $4.5 \%$, declining by about $10-15 \%$ thereafter.

\section{DISCUSSION}

Adding low calcium fly ash to a standard Portland cement raw mix lowers the lime saturation factor $(L S F)$ and silica 
nución del grado de saturación de cal (LSF) y del módulo de silicatos (SR), y por un aumento en el de aluminatos (AR). Esas variaciones significan generalmente una mejoría de las condiciones de clinkerización y una disminución de las temperaturas del proceso térmico (9-13).

El estudio de la descarbonatación del crudo se puede seguir dinámicamente mediante ATD. Durante el registro del termograma, una cantidad de calor dependiente de la diferencia de temperatura entre la muestra y el entorno induce la reacción de la muestra. $\mathrm{Al}$ comienzo de la descarbonatación la cinética química es lenta y la absorción de energía débil. Con el aumento de la temperatura la velocidad de reacción aumenta y la absorción de calor es máxima en el máximo del termograma. Esta evolución de la descarbonatación es debida a la lentitud de algunas etapas de la descomposición de la calcita. De acuerdo con Taylor (1) el mecanismo y la cinética de la descomposición de la calcita está controlada por las siguientes etapas: inicialmente se realiza la transferencia de calor desde la superficie exterior hacia la interfase, posteriormente las reacciones químicas tienen lugar en esa interfase, y finalmente el $\mathrm{CO}_{2}$ se transfiere hacia la superficie exterior.

La temperatura del principio de la descarbonatación aumenta con la adición de las cenizas volantes a causa de la modificación de las características químicas y físicas del crudo. La adición al crudo de las cenizas volantes bajas en cal permite una disminución en la proporción de $\mathrm{CaCO}_{3}$ y el crudo se enriquece en sílice. La presencia en proporciones elevadas de sílice, en forma de cuarzo, demanda largos periodos de tiempo para su clinkerización (13).

Probablemente el proceso de descarbonatación está controlado por la transferencia de calor desde la superficie exterior hacia la interfase. Partículas de tamaño muy grande retrasan la temperatura de descarbonatación, lo que obliga a moler la caliza hasta conseguir un tamaño de grano adecuado (14-17). Cuando tiene lugar la descarbonatación, la velocidad de descomposición de la caliiza aumenta mucho y la temperatura del máximo de la reacción, disminuye, ello se justifica por la incorporación de elementos que actúan como catalizadores.

La parte convexa del termograma, que se observa entre $t_{m}$ $\mathrm{y}_{\mathrm{c}}$ puede interpretarse como un efecto retrasado endotérmico de la descarbonatación o como el comienzo de la reacción exotérmica a causa de la formación de silicato bicálcico $\left(\mathrm{C}_{2} \mathrm{~S}\right)$, aluminato tricálcico $\left(\mathrm{C}_{3} \mathrm{~A}\right)$ y otros compuestos intermedios. En las muestras estudiadas en el presente trabajo se realizó un análisis mineralógico por Difracción de Rayos X y la asignación citada coincide con la que, a esas mismas temperaturas, hacen otros autores (18-21).

Los datos de las entalpías se obtienen por calorimetría isotérmica. Si a la temperatura prefijada se origina la ratio (SR), and raises the alumina ratio (AR). Such variations generally signal an improvement in burnability conditions as well as lower clinkering temperatures (913).

Raw mix decarbonation can be monitored dynamically with DTA. As the temperatures are recorded, a certain amount of heat, depending on the temperature difference between the sample and the surroundings, prompts the reaction in the sample. Chemical kinetics were observed to be slow and energy absorption weak in the early stages of decarbonation. Reaction rates rose with increasing temperature and heat absorption peaked at the thermogram peak. This decarbonation pattern is the result of the slow course of some phases of calcite decomposition, whose mechanism and kinetics are controlled, according to Taylor (1), by a number of steps. First, heat is transferred from the outer surface to the interface, where the chemical reactions take place in the following step, which is followed, finally, by the transfer of the carbon dioxide to the outer surface where it is subsequently released.

The decarbonation temperature increased at first with the addition of fly ash due to the modification of the chemical and physical properties of the raw mix, i.e., a lower $\mathrm{CaCO}_{3}$ and concomitant rise in silica content. The presence of large quantities of silica, which adopted the form of quartz, called for long burning times (13).

Decarbonation is most likely controlled by the transfer of heat from the outer surface to the interface: since the presence of large calcite particles in the siliceous raw mix retarded the rise in temperature at the beginning of the process, the samples had to be ground to obtain the proper particle size (14-17). Decarbonation accelerated limestone decomposition, whilst the peak reaction temperature dropped due to the addition of elements whose catalytic action consists of increasing the mean rate of decarbonation.

The convex part of the curve between $t_{m}$ and $t_{e}$ may be interpreted to be a delayed endothermic effect of decarbonation or the beginning of the exothermic reaction due to the formation of dicalcium silicate $(C, S)$, calcium aluminate $\left(C_{3} A\right)$ and other intermediate compounds. The $X R D$ identification of these phases in the samples generally concurred with the findings reported by other authors for the same temperatures (18-21).

Enthalpimetric data are obtained by isothermal calorimetry, integrating the effect of heat at a given 
descarbonatación, el termograma mostrará un efecto térmico hasta que la reacción haya finnalizado. El valor medido incluirá o no el total de la entalpía de la reacción, según se haya o no completado esa reacción. La descarbonatación comienza a temperaturas superiores a $1.020 \mathrm{~K}$. Esto se confirma por los valores de la entalpía a esa temperatura, la cual permanece constante. El contenido calorífico de la muestra libre de cenizas volantes $\left(\mathrm{RF}_{0}\right)$ no es significativamente diferente del que contiene $6 \%$ de cenizas $\left(\mathrm{RF}_{6}\right)$ Las capacidades caloríficas de los componentes no varían con las adiciones. En temperaturas más altas (1.126 y $1.237 \mathrm{~K})$ la descarbonatación se va haciendo más y más completa y aparece la reacción exotérmica. Por encima del $4,5 \%$ de adición de cenizas volantes las cinéticas de esas reacciones son, en conjunto, las mismas. Para concentraciones más altas, las medidas de la entalpía indican que las reacciones son menos endotérmicas, lo que supone que las reacciones exotérmicas son más completas. De acuerdo con los valores obtenidos, se comprueba que la entalpía disminuye entre 200 y $300 \mathrm{~J} / \mathrm{g}$ y además el $\mathrm{P}_{2} \mathrm{O}_{5}$ y el $\mathrm{Fe}_{2} \mathrm{O}_{3}$ actuarán -probablemente como catalizadores- en la reacción entre el $\mathrm{CaO}$ y el $\mathrm{SiO}_{2}$ para formar $\mathrm{C}_{2} \mathrm{~S}(1,22-25)$.

\section{CONCLUSIONES}

La modificación del crudo por adición de cenizas volantes bajas en cal, se refleja en la disminución del módulo de saturación de cal (LSF) y del módulo de silicatos (SR) y en un aumento en el de aluminatos (AR). La presencia de cenizas volantes en el crudo retarda el comienzo de la descarbonatación a causa del aumento en el contenido de sílice. El crudo se enriquece en silicatos y es preciso mucho tiempo para que comience la reacción de descarbonatación. Sin embargo disminuye la temperatura correspondiente al máximo de descarbonatación. Esto indica, en una primera fase de la clinkerización, que la velocidad de reacción media es más elevada a causa de la presencia de las cenizas volantes. Cuando $t>t_{m}$, ambas temperaturas, $\mathrm{T}_{\mathrm{m}}$ y $\mathrm{T}_{\mathrm{e}}$, indican la misma evolución $\mathrm{y}$ la velocidad de reacción media en la segunda fase de la clinkerización, es constante. La adición de cenizas volantes bajas en calcio parece disminuir algo el consumo de energía durante la descomposición de la caliza.

\section{AGRADECIMIENTOS}

Los autores agradecen al Dr. R. Castanet y a la Dra. H. Bros las ayudas prestadads para la realización de este trabajo. temperature over a long time period. If decarbonation occurs at a specific temperature, the thermal effect appears on the thermogram, providing the reaction is complete. The reading may or may not include the full enthalpy of reaction, depending on whether or not the reaction runs through to completion. Decarbonation began at temperatures of over $1020 \mathrm{~K}$, as confirmed by the fact that the enthalpy values taken at that temperature remained constant. The heat content of the sample to which no fly ash was added $\left(R F_{0}\right)$ was not significantly different from the sample containing $6 \%$ fly ash $\left(R F_{0}\right)$. The heat capacities of the constituents did not vary with the additions. Decarbonation ran closer and closer to completion as the temperature increased (1126 and $1237 \mathrm{~K})$, giving rise to exothermic reactions. Up to values of $4.5 \%$ of fly ash, the kinetics of these reactions were by and large the same. At higher concentrations the enthalpy measurements were less endothermic, an indication that the exothermic reactions had progressed further. Given that the decrease measured was on the order of 200 to $300 \mathrm{~J} / \mathrm{g}, \mathrm{CaO}$ and $\mathrm{SiO}$, must have taken part in the formation of $\mathrm{C}_{2} \mathrm{~S}$, whilst $\mathrm{P}_{2} \mathrm{O}_{5}$ and $\mathrm{Fe}_{2} \mathrm{O}_{3}$ probably acted as catalysts (1, 22-25).

\section{CONCLUSIONS}

The modification of raw mix prompted by the addition of low-calcium fly ash consists in a decrease in both the lime saturation factor (LSF) and the silica ratio (SR) and an increase in the alumina ratio $(A R)$. The presence of fly ash in the raw mix retards the onset of decarbonation due to enhanced silica content in the form of quartz. Subsequently, however, the temperature at the peak reaction rate falls, whilst the transformation reaction rate of materials at any given time, is the same as in the control. This indicates that the addition of fly ash raises the mean reaction rate in the early stages. At $t>t_{m}, T_{m}$ and $T_{e}$ evolve in parallel and the mean reaction rate in the second stage is constant. With the addition of low calcium fly ash, calcite decomposition appears to consume slightly less energy.

\section{ACKNOWLEDGMENTS}

The authors gratefully acknowledge the assistance provided by Dr. R. Castanet and H. Bros in connection with this study.

\section{BIBLIOGRAFÍA}

(1) H. F. W. Taylor, Cement Chemistry, Thomas Telford publishing, London, 1997.

(2) R. Bucchi, Influence of the nature and preparation of raw materials on the reactivity of raw mix, Pro.Int.Chem.Cem., $7^{\text {th }}$, vol. I, Paris, France, 1980, 1-3. 
(3) S. Sprung, Pro. Int. Chem. Cem., $7^{\text {th }}$, vol. I, Paris, France, 1980, 2-10

(4) F. M. Lea, The chemistry of cement and concrete, Arnold, London, 1970.

(5) U. Ludwing and R. Pohlmann, Investigation of the production of low lime portland cement, Pro. Int. Chem. Cem., $8^{\text {th }}$, vol. II, Río de Janciro, Brazil, 1986, 363-371.

(6) J. P.Meric, Low energy clinker formation, Pro.Int.Chem.Ccm., $8^{\text {th }}$, vol. I, Río de Janeiro, Brazil, 1986, 51-56.

(7) R. Castanet, F.P.Sorentino, Study of clinkering reactions by high temperature isothermal calorimetry, Pro. Int. Chem. Cem., $8^{\text {th }}$, vol. Il, Río de Janeiro, Brazil, 1986, 36-39.

(8) G. A. Uriano, Standard reference materials 720, synthetic Sapphire, Nat. Bur. Stand, US Department of Commerce, Washington, DC, 1986.

(9) J. P.Meric, Low energy clinker formation, Pro.Int.Chem.Cem., $8^{\text {th }}$, vol. I, Río de Janeiro, Brazil, 1986, 51-56.

(10) S. N. Ghosh, V. K. Mathur and S. K. Chopra, Low OPC-type cement containing super-hydraulic C,S phase, Cem. Concr. Res., 14 (1984) 437-438.

(11) H. Gygi, Thermodynamics of the cement kiln, Pro.Int. Chem. Cem., $3^{\text {rd }}$, London, UK, 1952, 750-779.

(12) E. Fundal, The burnability of cement raw mixes, World Cem. Techn., 10 (6) (1979) 195-204.

(13) G. R. Long, Clinker quality characterization by reflected light techniques, Pro. Int. Cem. Micr. Ass., $4^{\text {th }}$, Las Vegas, USA, 1982, 92-109.

(14) I. F. Petersen and V. Johansen, Cem. Concr: Res.,9 (1979) 631

(15) T. Heilmann, $3^{\text {rt }}$ ISCC (1954), 711

(16) U. Ludwig and G. Ruckensteiner, Cem. Concr: Res., 4 (1974) 239

(17) A. Fathi, Contribution à l'étude des phénomènes thermiques lors de la clinkerisation de cru de ciment portland, Thesis, Univ. Provence, Marseille, France, 1991.

(18) B. Couttin, A. Rouanet and M. Conjcaud, Pro. Int. Chem. Cem., $8^{\text {th }}$, Rio de Janeiro, Brazil, vol. II, 1986, 31-35.

(19) C. Ftikos and T. Philippou, Preparation and hydration study of rich $C_{2} S$ cements, Cem.Concr.Res., 20 (1990) 934-940.

(20) F. Sorrentino and R. Castanet, Application of thermal analysis to the cement industry, J. Therm. An., 38 (1992) $2137-2146$.

(21) S. C. Ahluwalia and V. K. Mathur, Thermal studies on the effect of transition metal oxides on the kinetics of formation and stabilization of $\beta$-dicalcium silicate, Pro.Int.Chem.Cem., $8^{\text {th }}$, Rio de Janciro, Brazil, vol. II, 1986, 40-45.

(22) My.Y. Benarchid, Influence des éléments mineurs ( $F e, C r$ ) sur la formation et la réactivité hydraulique du $C_{2} S$ et de $C_{3} A$. Identification de la phase $C_{f} A \bar{S}$ dans un clinker bélitique, Thesis, Univ. Mohammed V, Rabat, Morocco, 2002.

(23) G. K. Moir and F.P.Glasser, Mineralisers, Modifiers and activators in the clinkering process, Pro. Int. Chem. Cem., $9^{\text {th }}$, New Delhi, India, vol. I, 1992, 125-152.

(24) L. Halic\%, Y. Nathan, L. Ben-dor, The influence of $P_{2} O_{5}$ on clinker reactions, Cem. Concr. Res., 14 (1) (1984) $11-18$

(25) B. Matkovic and J. F. Young, Dicalcium silicate doped with phosphates, Pro. Int. Chem. Cem., $8^{\text {th }}$, Rio de Janeiro, Brazil, vol. II. 1986, 276-281. 


\title{
MMATERRALES DE GONSTRUGCOO゚N
}

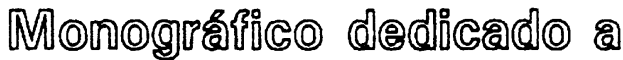

\section{LOS MATERIALES COMPUESTOS EN LA CONSTRUCCIORN}

La revista MATERIALES DE CONSTRUCCION, editada en el Instituto de Ciencias de la Construcción EDUARDO TORROJA, dedica un número doble (N 247/248) a: Los Materiales Compuestos en la Construccion.

Los Materiales Compuestos en la Construcción es una temática muy actual ya que incide en el desarrollo y aplicación de Nuevos Materiales ("Composites"), que son el futuro en el campo de la Construcción. Uno de los sectores productivos que más influyen en el PIB es el de la construcción, con lo cual resulta necesario involucrar al sistema de I+D en el desarrollo de nuevos materiales compuestos basados en el cemento. En estos términos se presentaba en la última convocatoria de proyectos de investigación de la CICCYT y dentro del Programa Nacional de Materiales, 10 referente a las investigaciones en el Area de Materiales Compuestos (B.O.E. 7 de noviembre de 1997). Los Materiales Compuestos en la Construcción constituyen un tema estratégico, tanto para los ingenieros de caminos, canales y puertos como para los ingenieros de materiales.

Este número monográfico se compone de dos partes. La parte I se dedica a los materiales compuestos de matríz de hormigón. Son tratados temas claves como la dosificación, la interfase en sistema acero-hormigón y la implantación de nuevas fibras como son las acrnicas. La parte II se concentra en los denominados materiales compuestos de matriz orgánica, analizándose en profundidad las nuevas tecnologlas tipo sandwich, textiles o de parrilla.

En este número especial se recogen trabajos de investigación originales e inéditos, en los que también se presentan las amplias posibilidades de aplicación de estos materiales. Los autores de estos trabajos, tanto los nacionales como los internacionales, son especialistas reconocidos en su respectivos campos cientfficos.

Los articulos que componen este número especial son:

- Materides Compuestos on la Construcción: Introducción (Composite Materials in Building: Introduction)

A. Miravoto

- Dosificación de hormigón reforzedo con fibres de acero (Mix design of steel fiber reinforced concrete) E. Moreno y M. Fernández Cánovas

- Estudio de la interfase on los hormigones roforzedos con fibres (Interfaces study of fiber reinforced concrete) A. Pecios y M. Fornóndez Cónovas

- Hormigónes roforzados con fibres acrlicas (Concretes reinforced with acrylic fibres) T. Amat

- Fabricación y diseño de estructuras parrills (Manufocture and desion of composite grids) Stophon W. Tsai, Kovin K.S. Liu y Ptrilippo M. Manno

- Caractorfaticas de los olemontos resistentes tipo sandwich construidos en materiales compuestos avanzedos a partir de tojidos tridimensionalos (Characteristics of sendwich-type structurel elements built of advanced composite materials from three dimonsional fabricsl

L. Cestojón, M.A. Jimónez y A. Miravote

- Meterial es compuestos realizados a partir de nuevas tecnologías textiles (Composite materials from new textile technologies) M.A. Jimónez, L. Castojón y A. Miravoto

- Los compositos y la construcción: su ayor, hoy y mañana (Composites and construction: yosterday, today and tomorrow) J. Manso

- Conclusiones findes (Final consc/usions) A. Miravoto 